\title{
Penentuan Kualitas Air Minum Isi Ulang terhadap Kandungan Total Kromium, Nitrat, Nitrit, Total Zat Padat Terlarut, Suhu, dan pH
}

\author{
Ita Emilia \\ e-mail : itaemilia742@gmail.com \\ Program Studi Biologi Fakultas Matematika dan Ilmu Pengetahuan Alam \\ Universitas PGRI Palembang
}

\begin{abstract}
Refill drinking water is one alternative in meeting drinking water needs for the people of Palembang City. However, many do not know the quality of refill drinking water that is in accordance with drinking water quality standards. This study aims to describe the quality of drinking water produced by several refill drinking water depots located in the area of Seberang Ulu I and Seberang Ulu II, Palembang City, South Sumatra. This study uses a descriptive survey method to get an overview of the parameters that are directly related to health, including testing total chromium, nitrate and nitrite. Parameters that are not directly related to health include physical parameters, namely total dissolved solids (TDS) and temperature, and chemical parameters including testing $\mathrm{pH}$ levels. Samples of refill drinking water were taken as many as five samples using Purposive Sampling techniques using a uv-vis spectrophotometer. This research was conducted at the BTKLPP Laboratory (Center for Environmental Health Engineering and Disease Control) of South Sumatra Province, Indonesia. The results showed that the five samples of refill drinking water fulfilled the requirements stipulated under the Regulation of the Minister of Health of the Republic of Indonesia No. 492/MENKES/PER/IV/2010. For the fifth sample, acid $\mathrm{pH}$ was based on KEP.MEN.KES RI No. 492/ MENKES/PER/IV/2010.
\end{abstract}

Keywords : quality determination, refill drinking water, physical, chemical

\begin{abstract}
ABSTRAK
Air minum isi ulang merupakan salah satu alternatif dalam memenuhi kebutuhan air minum untuk masyarakat Kota Palembang. Akan tetapi banyak yang belum mengetahui kualitas air minum isi ulang yang telah sesuai dengan standar kualitas air minum. Penelitian ini bertujuan untuk mengetahui gambaran kualitas air minum yang dihasilkan beberapa depot air minum isi ulang yang berada di kawasan daerah Seberang Ulu I dan Seberang Ulu II, Kota Palembang Sumatera Selatan. Penelitian ini menggunakan metode survey yang bersifat deskriptif untuk mendapatkan gambaran mengenai parameter yang berhubungan langsung dengan kesehatan , meliputi pengujian total kromium, nitrat dan nitrit. Parameter yang tidak langsung berhubungan dengan kesehatan meliputi parameter fisik, yaitu total zat padat terlarut (TDS) dan suhu, serta parameter kimiawi meliputi pengujian kadar $\mathrm{pH}$. Sampel air minum isi ulang diambil sebanyak lima sampel dengan menggunakan teknik Purposive Sampling dengan menggunakan spektrofotometer uv-vis. Penelitian ini dilaksanakan di Laboratorium BTKLPP (Balai Teknik Kesehatan Lingkungan dan Pengendalian Penyakit) Provinsi Sumatera Selatan, Indonesia. Hasil penelitian menunjukkan bahwa kelima sampel air minum isi ulang memenuhi persyaratan yang ditetapkan berdasarkan Peraturan Menteri Kesehatan Republik Indonesia No.492/MENKES/PER/IV/2010. Untuk sampel kelima, pH asam berdasarkan KEP.MEN.KES RI No. 492/MENKES/PER/IV/2010.
\end{abstract}


Kata Kunci : penentuan kualitas, air minum isi ulang, fisik, kimia

\section{PENDAHULUAN}

Pengadaan air bersih untuk kepentingan rumah tangga seperti untuk air minum, air mandi dan sebagainya harus memenuhi persyaratan yang sudah ditentukan oleh pemerintah Republik Indonesia. Dalam hal ini persyaratan kualitas air minum harus sesuai dengan ketentuan yang tercantum dalam Keputusan Menteri Kesehatan RI No. 907/MENKES/VII/2002, dimana setiap komponen yang terkandung dalam air minum harus sesuai dengan yang Air minum merupakan kebutuhan manusia yang paling penting. Seperti diketahui, kadar air tubuh manusia mencapai 68 persen, dan untuk tetap hidup air dalam tubuh tersebut harus dipertahankan. Padahal, kebutuhan air minum setiap orang bervariasi dari 2,1 liter hingga 2,8 liter per hari, tergantung pada berat badan dan aktivitasnya. Namun, agar tetap sehat, air minum harus memenuhi persyaratan fisik, kimia, maupun bakteriologis. Jika kekurangan air, maka proses metabolisme akan terganggu. Akibatnya bisa terjadi dehidrasi, yang pada tahapan lebih lanjut bisa menimbulkan kematian (Hazimah \& Triwuri, 2017; Nasir \& Apriani, 2009)

Menurut perhitungan WHO di Negara-negara maju tiap orang memerlukan air antara 60120 liter per hari, sedangkan di Negara-negara berkembang, termasuk Indonesia tiap orang memerlukan air antara 30-60 liter per hari. Pada tahun 2014 penggunaan air bersih di Indonesia yaitu 3,032 miliar $\mathrm{m}^{3}$. Air minum adalah air yang kualitasnya memenuhi syarat kesehatan dan dapat langsung diminum, syarat kesehatan yang dimaksud adalah mikrobiologi; kimia fisika dan radio aktif (Maria dan Margareth, 2016).

Meningkatnya permintaan masyarakat akan air minum isi ulang yang ditetapkan. Air minum selain merupakan kebutuhan esensial, namun juga berpotensi sebagai media penularan penyakit, keracunan dan sebagainya (Nur'aini $d k k, 2015)$. Oleh sebab itu, air merupakan benda yang harus selalu ada bagi manusia. Bagi manusia, air diperlukan untuk menunjang kehidupan, antara lain dalam kondisi yang layak diminum tanpa mengganggu kesehatan (Gafur $d k k .$, 2017).

hemat dan praktis diimbangi dengan banyaknya usaha depot air minum isi ulang yang bermunculan. Air minum isi ulang memang dapat dijadikan salah satu solusi untuk memenuhi kebutuhan air minum masyarakat yang semakin tinggi. Akan tetapi, dikarenakan belum adanya standarisasi dalam peraturan untuk proses pengolahan air, maka kualitas air minum isi ulang ini masih sering diperdebatkan. Oleh karena itu depot tidak dapat menjamin bahwa air yang diproduksinya sesuai kualitas standar air minum (Marpaung dan Marsono, 2013).

Keberadaan produk yang dihasilkan oleh Depot Air Minum Isi Ulang (DAMIU) disambut baik oleh masyarakat, hal ini menunjukkan upaya mewujudkan masyarakat sehat karena memperluas jangkauan air bersih, namun saat ini DAMIU menjadi cenderung bermasalah ketika dihadapkan dengan kepentingan bisnis, tak jarang para pengusaha dan pengelola/penjamah DAMIU lalai dalam berbagai aspek baik itu kebersihan bengunan dan alat, perawatan alat, maupun kebersihan diri penjamah tersebut. Sehingga seringkali kualitas dari air minum yang dihasilkan tidak layak konsumsi (Maria dan Margareth, 2016).

Meninjau dari permasalahan tersebut, maka perlu dilakukan uji kualitas 
air minum isi ulang dengan menguji beberapa parameter yang berhubungan langsung dengan kesehatan, seperti pengujian kimia anorganik meliputi pengujian total kromium, nitrat, dan nitrit. Parameter yang tidak langsung berhubungan dengan kesehatan, antara lain parameter fisik yaitu pengujian total zat padat terlarut (TDS) dan suhu. Parameter kimia, yaitu pengujian $\mathrm{pH}$. Diharapkan dari penelitian ini dapat memberikan kontribusi informasi kualitas air minum isi ulang yang dikonsumsi masyarakat.

Sampel yang dianalisa diambil dari air minum isi ulang pada depot-depot sebagai berikut:

Sampel 1 :

di daerah Tajur, Seberang Ulu I

Sampel 2 :

di daerah Dua Saudara, Seberang Ulu II

Sampel 3 :

di daerah Patmajaya, Seberang Ulu I.

Sampel 4 :

di daerah Yaktapena 1, Seberang Ulu II

Sampel 5 :

di daerah Tembok Baru, Seberang Ulu I

Peralatan yang digunakan Spektrofotometri UV- Vis Shimatzu 1800, timbangan analitik metler toledo, water bath, lampu holow katoda $\mathrm{Cr}^{-}$, gelas piala $250 \mathrm{~mL}$, pipet ukur, labu ukur $100 \mathrm{~mL}$, corong gelas, erlenmeyer, pemanas listrik, kertas saring whatman 40, dengan ukuran pori $\theta 0.42 \mu \mathrm{m}$, labu semprot.. Bahan yang digunakan meliputi, natriun nitrit, kalium nitrat, asam sulfanilat, asam klorida, N-(1naftil etilendiamin dihidroklorida, glisin, natrium hidroksida, naftil etilendiamin dihidroklorida, air suling, asam nitrat, $\mathrm{HNO} 3$, larutan standar logam krom, $\mathrm{Cr}^{-}$, gas asetilen, $\mathrm{C}_{2} \mathrm{H}_{2}$.

\section{BAHAN DAN METODE}

Penelitian ini menggunakan metode survey yang bersifat deskriptif untuk mendapatkan gambaran tentang kualitas air minum dengan parameter kandungan total kromium $(\mathrm{Cr})$, nitrat $\left(\mathrm{NO}_{3}{ }^{-}\right)$, nitrit $\left(\mathrm{NO}_{2}{ }^{-}\right)$, totat zat padat terlarut atau total dissolved solid (TDS), Suhu, dan $\mathrm{pH}$. Penelitian ini dilaksanakan di Laboratorium BTKLPP (Balai Teknik Kesehatan Lingkungan dan Pengendalian Penyakit) Provinsi Sumatera Selatan.

Penetapan kadar total kromium (Cr) : dimasukkan sebanyak $100 \mathrm{~mL}$ contoh uji yang sudah dikocok sampai homogen kedalam gelas piala., ditambahkan $5 \mathrm{~mL}$ asam nitrat. Selanjutnya dipanaskan di pemanas listrik sampai larutan contoh uji hampir kering. Ditambahkan $50 \mathrm{~mL}$ air suling, masukan ke dalam labu ukur $100 \mathrm{~mL}$ melalui kertassaring dan ditepatkan $100 \mathrm{~mL}$ dengan air suling (SNI 6989.17:2009)

Penetapan kadar nitrit: Sebanyak 3 $\mathrm{mL}$ sampel dan $2 \mathrm{~mL}$ larutan asam sulfanilat dimasukkan ke dalam tabung reaksi. Dibiarkan bereaksi selama 10 menit. Ditambahkan dengan $2 \mathrm{~mL}$ larutan naftil etilendiamin dihidroklorida, diaduk dan dibiarkan bereaksi selama 30 menit. Larutan dimasukkan ke dalam kuvet dan dibaca absorbansinya pada panjang gelombang $535 \mathrm{~nm}$ (SNI 06-6989.92004).

Penetapan kadar nitrat : Sebanyak $1 \mathrm{~mL}$ sampel ditambahkan 0,5 - 1,5 g granul Zn. Dibiarkan bereaksi selama 10 menit, kemudian granul $\mathrm{Zn}$ dipisahkan dan larutan digenapkan dalam labu ukur $10 \mathrm{~mL}$. Dari larutan tersebut diambil $3 \mathrm{~mL}$ dan $2 \mathrm{~mL}$ larutan asam sulfanilat dimasukkan ke dalam tabung reaksi. Dibiarkan bereaksi selama 10 menit. Ditambahkan dengan $2 \mathrm{~mL}$ larutan naftil etilendiamin dihidroklorida, diaduk dan dibiarkan bereaksi selama 30 menit. Larutan dimasukkan ke dalam kuvet dan 
dibaca absorbansinya pada panjang gelombang $535 \mathrm{~nm}$ (SNI 06-2480.1991).

HASIL DAN PEMBAHASAN
Berdasarkan hasil pemeriksaan terhadap kelima sampel yang berisi air minum isi ulang diperoleh data seperti ditunjukkan pada tabel 1.

Tabel 1. Hasil pemeriksaan kimia anorganik, parameter kimia dan fisik dalam sampel air minum isi ulang

\begin{tabular}{ccccccc}
\hline Parameter & $\mathbf{1}$ & $\mathbf{2}$ & $\begin{array}{c}\text { Sampel } \\
\mathbf{3}\end{array}$ & $\mathbf{4}$ & $\mathbf{5}$ & $\begin{array}{c}\text { Batas } \\
\text { Maksimum }\end{array}$ \\
\hline $\begin{array}{c}\text { Total } \\
\text { Kromium } \\
\text { Nitrat }\end{array}$ & $<0.003$ & $<0.003$ & $<0.003$ & $<0.003$ & $<0.003$ & $0.05 \mathrm{mg} / \mathrm{L}$ \\
$\begin{array}{c}\text { Nitrit } \\
\text { Total Zat }\end{array}$ & 0.019 & 0.018 & 0.013 & 0.016 & 0,037 & $50 \mathrm{mg} / \mathrm{L}$ \\
$\begin{array}{c}\text { Padat Terlarut } \\
\text { Suhu }\end{array}$ & 99 & 59 & 65 & 31 & 45 & $500 \mathrm{mg} / \mathrm{L} / \mathrm{L}$ \\
& 27.6 & 27,5 & 27.5 & 27.5 & 27.3 & ${ }^{0} \mathrm{C}$, Suhu Udara \pm \\
pH & 7.98 & 7.26 & 7.20 & 7.19 & 4.55 & 3 \\
\hline
\end{tabular}

Keterangan : Memenuhi persyaratan yang telah ditetapkan berdasarkan KEP.MEN.KES RI No. 492/MENKES/PER/IV/2010

Konsentrasi total kromium untuk kelima sampel masih di bawah batas maksimum, yaitu $<0.003 \mathrm{mg} / \mathrm{L}$. Krom (Cr) di alam berada pada valensi $3\left(\mathrm{Cr}^{3+}\right)$ dan valensi $6\left(\mathrm{Cr}^{6+}\right) . \mathrm{Cr}^{6+}$ lebih toksik dibandingkan dengan $\mathrm{Cr}^{3+}$, karena sifatnya yang berdaya larut dan mobilitas tinggi di lingkungan (Rahman et al., 2007). Melalui rantai makanan kromium dapat terdeposit pada bagian tubuh makhluk hidup yang pada suatu ukuran tertentu dapat menyebabkan racun (Mulyani, 2004). Apabila masuk ke dalam sel, dapat menyebabkan kerusakan struktur DNA hingga terjadi mutasi (Larashati, 2004). Terakumulasinya krom dalam jumlah besar di tubuh manusia jelas-jelas mengganggu kesehatan karena krom memiliki dampak negatif terhadap organ hati, ginjal serta bersifat racun bagi protoplasma makhluk hidup. Selain itu juga bersifat karsinogen (penyebab kanker), teratogen (menghambat pertumbuhan janin) dan mutagen (Schiavon et al., 2008)

Untuk senyawa nitrat yang paling tinggi terkadung dalam sampel air minum nomor 5, yaitu sebesar $4.80 \mathrm{mg} / \mathrm{L}$.
Konsentrasi nitrit yang paling tinggi juga terdapat dalam sampel 5, yaitu 0.037 $\mathrm{mg} / \mathrm{L}$. Konsentrasi nitrat terendah terlihat pada sampel 3 dan 4, yaitu sebesar 3.10 $\mathrm{mg} / \mathrm{L}$. Konsentrasi nitrit terendah pada sampel 3 dan 4, yaitu masing-masing sebesar $0.013 \mathrm{mg} / \mathrm{L}$ dan $0.016 \mathrm{mg} / \mathrm{L}$.

Parameter fisik meliputi pengujian total zat padat terlarut atau total dissolved solid (TDS) menunjukkan hasil terlihat pada tabel 1, yaitu masih di bawah batas maksimum yang ditetapkan berdasarkan KEP.MEN.KES RI No. 492/MENKES/PER/IV/2010, yaitu di bawah $500 \mathrm{mg} / \mathrm{L}$. Jika konsentrasi TDS tinggi dapat mempengaruhi rasa dari air minum dan memperlihatkan hubungan negatif dengan beberapa parameter lingkungan air yang menyebabkan meningkatnya toksisitas pada organisme didalamnya. Parameter fisik lainnya adalah pengujian terhadap suhu air minum isi ulang. Suhu termasuk dalam kategori parameter fisika. Suhu air yang melebihi batas normal menunjukkan indikasi terdapat bahan kimia yang terlarut dalam jumlah yang cukup besar atau sedang terjadi proses dekomposisi bahan organik 
oleh mikroorganisme yang berbahaya bagi tubuh.

Parameter terakhir adalah adalah $\mathrm{pH}$ air yang merupakan parameter kimia organik. Nilai $\mathrm{pH}$ yang lebih dari 7 menunjukkan sifat korosi yang rendah sebab semakin rendah $\mathrm{pH}$, maka sifat korosinya semakin tinggi. Nilai $\mathrm{pH}$ air yang lebih besar dari 7 memiliki kecenderungan untuk membentuk kerak dan kurang efektif dalam membunuh bakteri sebab akan lebih efektif pada kondisi netral atau bersifat asam lemah. Dari kelima sampel air minum isi ulang menunjukkan sampel 1, 2, 3, dan 4 memenuhi persyaratan yang telah ditetapkan berdasarkan KEP.MEN.KES RI No. 492/MENKES/PER/IV/2010. pH air minum sampel ke5 sebesar 4.55 bearti air minum pada sampel 5 bersifat asam, keadaan seperti ini tidak baik untuk tubuh manusia.

\section{KESIMPULAN}

Pengujian beberapa parameter yang berhubungan langsung dengan kesehatan meliputi pengujian total kromium (Cr), nitrat (sebagai $\mathrm{NO}_{3}{ }^{-}$) dan dan nitrit (sebagai $\mathrm{NO}_{2}{ }^{-}$) dan parameter yang tidak langsung berhubungan dengan kesehatan (total zat padat terlarut, suhu, $\mathrm{pH}$ ) terhadap kelima sampel air minum isi ulang yang diambil di lima daerah di Seberang Ulu I dan II, Kota Palembang Sumatera Selatan. menunjukkan bahwa kelima sampel air minum isi ulang memenuhi persyaratan yang ditetapkan berdasarkan Peraturan Menteri Kesehatan Republik Indonesia No.492/MENKES/PER/IV/2010. Untuk sampel kelima, $\mathrm{pH}$ asam berdasarkan KEP.MEN.KES RI No. 492/MENKES/PER/IV/2010.

\section{DAFTAR PUSTAKA}

Gafur , Abd., Andi Darma Kartini, Rahman. (2017). Studi Kualitas
Fisik Kimia dan Biologis pada Air Minum dalam Kemasan Berbagai Merek yang Beredar di Kota Makassar Tahun 2016. Journal Hiegine . 3(1).

Hazimah, H., \& Triwuri, N. A. (2017). Feasibility Test of Refill Drinking Water in Batam. Journal of Dynamics, 2(1).

Larashati, S. (2004). Reduksi Krom (Cr) Secara In Vitro oleh Kultur Campuran Bakteri yang Diisolasi dari Lindi Tempat Pembuangan Akhir Sampah (TPA). Thesis : ITB.

Maria, R. W., and Margareth Sapulete, J. P. (2016). Gambaran Kualitas Air Minum dari Depot Air Minum isi Ulang di Kelurahan Ranotana-Weru dan Kelurahan Karombasan Selatan Menurut Parameter Mikrobiologi. Kedokteran Komunitas dan Tropik, 4.

Marpaung, D. O. M., and Marsono, B.D. (2013). Uji Kualitas Air Minum Isi Ulang di Kecamatan Sukolilo Surabaya Ditinjau dari Perilaku dan Pemeliharaan Alat . JURNAL TEKNIK POMITS, 2(2). 23373539.

Mulyani, B. (2004). Analisis Variasi Biomassa Saccharomyces cerevisiae terhadap Serapan Logam Krom. Sain. 2(4). 1-9.

Nasir, S., A, W. W. K., and Apriani, R. (2009). The Equivalentcy of Quality of Water In Filtration Process and UF Membrane Process. Jurnal Teknik Kimia. 16(1). 46-54.

Iqbal, I. Analysis of the levels of heavy Metal in refill using Atomic Absorption Spectrophotometry (AAS). Gravitasi, 14(1). 
Rahman, M,U., Gul S., Ulhaq, M.Z. (2007). Reduction Of Chromium (VI) by Locally Isolated Pseudomonas sp. C171. Turkey Journal Biol , 31, 161-166.

Schiavon, M. E. A. H. Pilon. Smits, M. Wirtz, R. Hell and M. Malagoli. (2008). Interactions Between Chromium And Sulfur Metabolism In Brassica juncea. Journal of
Enviromental Quality, 37, 15361545.

Timpano, A.J., S.H. Schoenholtz, C.E. Zipper, D.J. Soucek. (2010). Isolating effects of total dissolved solids on aquatic life in central Appalachian coalfield streams. Proceedings America Society of Mining and Reclamation, 12841302. Tersedia di: http://www.asmr.us/Publications/ 